\title{
Risk Perception and Occupational Accidents among a Group of Egyptian Construction Workers in Cairo, Egypt
}

\author{
Manar M. Ellaban ${ }^{1}$, Mervat H. Rady ${ }^{1}$, Hebat Allah MS. Gabal ${ }^{1}$, Nayera S. Mostafa ${ }^{1 *}$ \\ ${ }^{1}$ Department of Community, Environmental and Occupational Medicine, Faculty of Medicine, Ain Shams
}

University

\begin{abstract}
:
Background: Construction sector is one of the risky businesses in which fatal and non-fatal occupational injuries occur frequently. Information about workers' awareness about health hazards, risk perception, and safe work practices can help in implementing prevention strategies. Unfortunately, construction sites had limited access for research, accounting only for $2.28 \%$ of all available researches. Objectives: The current study aimed to estimate the perception of construction workers to the occupational hazards. Also, it aimed at identifying types of common occupational accidents involving construction workers in an Egyptian company, and to identify the workers' personal and work-related characteristics of their risk perception. Methods: A cross-sectional study was conducted among construction workers in one of the projects in Cairo. During the period from January to August 2018, 104 workers were interviewed using a structured questionnaire inquiring about sociodemographic characteristics and work-related variables together with assessment of workers' risk perception. Results: The majority of the workers had low risk perception for falls, contact with chemicals, being struck by objects, sharp objects, manual lifting, repetitive movements, and heat stress, while noise was reported to be in "no or acceptable risk" category. The study identified age, health and safety training, working hours, and the use of Personal Protective Equipment (PPE) as significantly related factors to risk perception. Conclusion: Risk perception among studied workers in average is low. Older age, prolonged working hours, lack of training, and not wearing PPE are significant risk factors shaping workers' perception. Safety training and change of work environment may reduce the risk of injuries.
\end{abstract}

Keywords: Awareness, Egypt, Construction workplace, Safety.

\section{Introduction:}

Construction industry is an economic investment, as construction workers represent around 180 million people, or $7 \%$ of global employment. The construction sector in Egypt is one of the main contributors to the country's economy and one of its fastest growing sectors, making up about $70 \%$ of casual wage workers. ${ }^{1}$ However, construction industry is a very hazardous industry where fatal and non-fatal occupational injuries occur frequently due to the unique environment of the construction industry, human behavior, harsh working conditions, and poor safety management. $^{2}$ The main causes of construction workers' fatalities are falls, being struck by objects, electrocution, and caughtin/-between hazards. Globally, in 2016, it was estimated that $21 \%$ of occupational fatalities were recorded in construction. ${ }^{3}$ According to a study conducted in Egypt, approximately 13\% of work-related deaths and $18 \%$ of occupational injuries were recorded in construction. ${ }^{1}$ Occupational injuries and illnesses have a huge impact not only on safety and health, but also on the high

*Corresponding author: E-mail: Nayera_samy@med.asu.edu.eg 
economic impact. ${ }^{4}$ It has been shown that failure to deal with risks effectively results in cost and time overruns in construction projects. Risk is a calculation of the probability of the hazard to occur and the severity of its consequences. Being able to accurately assess the risk in a situation is, at a personal level, dependent on an individual's risk perception and risk tolerance. ${ }^{2,5}$ Risk perception is the ability of an individual to determine a certain amount of risk, and risk tolerance refers to a person's ability to accept a certain amount of risk.

Studying the risk perception of workers is therefore important, as individuals are responsible for the perceived risks in their work environment. ${ }^{6}$ When workers are aware of the health and safety risks in their workplace, they can follow safe work practices. Information about workers' current and changing awareness about health and safety hazards, risk perception, and safe work practices can help to understand where prevention strategies should be applied. ${ }^{5}$ Unfortunately, construction sites are workplaces with limited access for research; studies at work level represent only $2.28 \%$ of all available researches, making it necessary to pay more attention to safe construction environment. ${ }^{7}$ The objectives of this study were as follows: to estimate the perception of a group of construction workers to the hazards in their work environment, to identify the role of workers' personal and work-related characteristics on their risk perception, and to identify common occupational accidents' types involving construction workers in an Egyptian company.

\section{Methods:}

Research Design: A cross-sectional study was conducted.

Study Setting: The study was conducted in one of the construction projects running in Cairo.

Time of the Study: The study was conducted during the period from January to August 2018.

\section{Population and Sample}

Study Population: The study included a sample of Egyptian construction workers in a project in Cairo.

Inclusion Criteria: All types of construction workers in the assigned project who are working in the construction sector at least for 6 months and agreed to participate in the study were included.

Exclusion Criteria: Managerial personnel, engineers, and employees responsible for health and safety of staff and workplace were excluded. 


\section{Study Sample:}

Sampling Method: A convenience sample of construction workers at the project was recruited; the construction project site was visited 3 days a week till the required sample size was reached.

Sample Size: Assuming a proportion of workers who properly perceived the risk of a certain hazard to be high or permanent, a proposed $50 \%$ will yield the maximum sample size of 104 which produces a two-sided $95 \%$ confidence interval with a width equal to $20 \%$ (40\%-60\%) using PASS 11 program.

Study Variables: Independent variables of the current study are sociodemographic characteristics and work-related variables, while the dependent variable is workers' risk perception.

Study Tools: A structured interview questionnaire was used to collect the necessary data about workers and workplace at the construction project. The questionnaire included the following: Section I, sociodemographic characteristics of the studied workers (e.g., age, education, occupation, marital status, and smoking habit); Section II, work-related variables (e.g., type of contract, working hours per week, duration of work in construction and in current job, experience of injuries in the last year, wearing PPE, receiving health and safety training, their opinion about types of hazards in their workplace, and the frequency of these hazards); Section III, assessment of workers' risk perception towards their occupational hazards using the classic Risk Formula:

Risk $=\mathrm{P}^{*} \mathrm{D}$, where $\mathrm{P}$ is the probability of threat (i.e., the likelihood) and D is the expected damage (i.e., the severity), for quantitative risk assessment, and then the risk perception was classified as follows:

- Acceptable/no risk (1-4).

- Low risk (5-9).

- Medium risk (10-15).

- High risk (16-25) $8-11$

Pilot Study: A pilot study was carried out on 20 workers and the required modifications of the questionnaire were performed by adding a choice of a prolapsed disc in the question about types of occupational injuries the worker has experienced and a choice of goggle and mask in the question about the types of personal protective equipment used. Pilot data were excluded from the study results.

\section{Data Management and Analysis:}

The collected data was revised, coded, tabulated, and introduced to personal computer and then analyzed using SPSS program (Statistical Package for Social 
Sciences) for Windows Version 22.

Qualitative data were presented as frequencies and percentages, while quantitative variables were presented as mean and standard deviation (SD). Chi square test and Fisher's Exact test were used and level of significance used was $\mathrm{p} \leq 0.05$.

\section{Ethical Consideration:}

The required ethical and administrative approvals were obtained and informed verbal consent was obtained from each participant. To assure the confidentiality, the questionnaire was anonymous.

\section{Results:}

The current study included 104 workers who were working in one of the construction projects in Cairo. More than half of the workers $(60.6 \%)$ were adolescents and young adults; their age ranged from 15 to 65 years with mean \pm about $31 \pm 12$ years, nearly half of the studied workers (45.2\%) had completed secondary or technical school, $63.5 \%$ were married, and $58.7 \%$ were current smokers. More than half of the current smokers (62.3\%) were smoking usually during working time (Table-1).

Regarding participants' work related data, $77.9 \%$ of the workers were working according to a part-time contract; the duration of working in construction ranged from 0.5 to 50 years with mean \pm SD about $14 \pm 12$ years, while the duration of working in current job ranged from 0.1 to 40 with mean \pm SD about 6 \pm 8 years. The working hours per week ranged from 10 hours to 72 hours with mean \pm SD of $50.5 \pm 8$ hours. Regarding their occupation, the current study showed that painters represented the highest percentage of the selected workers (28.8\%) followed by carpenters $(20.2 \%)$ and construction laborer (18.3\%) as shown in Table-2.

Concerning experience of injuries at work, $59.6 \%$ of the studied workers had experienced injuries during the last year, of which the most frequently encountered injuries were contusions $(48.1 \%)$ and abrasions (45.2\%) followed by fractures (37.5\%) (Table-3). Regarding the PPE, 68.3\% of the workers were wearing PPE and the most frequently used PPE was safety shoes $(57.7 \%)$ and the least was mask and goggle (2.9\% each) (Table 4).

Regarding health and safety training, $61.5 \%$ of the workers reported that they had never received training about all the reported hazards. The very frequent hazards were repetitive movements $(88.5 \%)$, noise $(87.5 \%)$, contact with chemicals $(73.1 \%)$, and heat stress $(61.5 \%)$ followed by manual lifting 
$(58.7 \%)$ and sharp objects $(58.7 \%)$, while collapse (84.6\%), fall (76\%), and being struck by objects $(52.9 \%)$ were reported as quite frequent hazards.

As regards the probability, the present study showed that repetitive movements were reported by $20.2 \%$ of the workers as being very likely to cause injuries and other hazards were reported to cause injuries sometimes, while noise and heat stress were reported to never cause injuries by $29.8 \%$ and $17.3 \%$ of the workers, respectively.

Concerning severity of the studied hazards, the current study found that nearly two-thirds of the workers reported that being struck by objects, repetitive movements, and noise are less severe hazards and cause injuries that do not require medical intervention; also, sharp objects and manual lifting were reported as less severe hazards by $54.8 \%$ and $36.5 \%$ of the workers, respectively.

Approximately half of the workers considered fall, collapse, and contact with chemicals as hazards which cause injuries requiring medical intervention. However, noise, heat stress, and repetitive movements are reported as not severe hazards at all by $38.5 \%, 25 \%$, and $23.1 \%$, respectively. Study results revealed that the majority of the workers had low risk perception for all the hazards except for the noise as its risk perception ranged between no risk/ acceptable risk by nearly half of the workers as shown in Table-5.

Concerning the factors affecting the level of workers' perception of different types of their occupational hazards, the present study found that there was a statistically significant relationship between age and risk perception of repetitive movements $(\mathrm{p}=0.043)$, while a statistically significant relationship was revealed between working hours per week and manual lifting $(\mathrm{p}=0.026)$. Additionally, risk protection perception of wearing PPE was significantly related to perception of manual lifting $(\mathrm{p}=0.0136)$, repetitive movements $(\mathrm{p}=0.007)$, and heat stress $(p=0.003)$.

Moreover, there was a statistically significant relationship between receiving health and safety training and risk perception of contact with chemical ( $\mathrm{p}=0.007)$, improper manual lifting $(\mathrm{p}=0.032)$, repetitive movements $(p=0.042)$, and noise $(p=0.020)$. Bivariate analysis shows that there was significant correlation between age and perception of repetition (-0.264, P-value $=0.007$ ), weekly working hours and perception of manual handling (-0.217, 
P-value 0.027), and number of missed working days and perception of collapse $(-0.293$, P- value 0.021$)$.

\section{Discussion:}

Risk perceptions are important determinants of health- and risk-related decisions such as the adoption of healthy behaviors and the use of PPE, and they contribute a lot to safety management and curtail unhealthy behaviors. ${ }^{12,13}$ The present study revealed that more than half of the participated workers had experienced injuries in the last year (59.6\%). This rate is higher than that in a previous Egyptian study in 2013, conducted by Abbas et al., which revealed that $46.2 \%$ of workers had experienced occupational injuries in the past 12 months. ${ }^{1}$

Also in Italy, Antonucci et al. reported that $28.3 \%$ of the workers reported their experience of at least one accident during their working life and Dong found that approximately $11.5 \%$ of the construction workers in Hong Kong reported they had experienced a work-related injury during their working life. ${ }^{11,14}$

This disagreement may be due to better safety measures, strict supervision of work environment, and the use of PPE in western countries or may be due to the younger age of the present study workers making them prone more to accidents. The most frequently encountered injuries among our study participants were contusions, abrasions, fractures, eye injuries, ear injuries, and disc prolapse. This result nearly agrees with that of a previous study in 2012 conducted by Elsafty et al. who reported that the majority of injuries reported in Egypt were eyes injuries, shoulder and back pain, and sprain in ankles. ${ }^{15}$

As regards the probability of the studied hazards, the present study showed that all the studied hazards were reported as more likely to cause injuries with the exception of noise and heat stress which never cause injuries. Concerning the severity, about half of the workers considered fall as hazard which causes injuries requiring medical intervention. This result agrees with Antonucci et al. study determining that sharp objects, manual lifting, and falling from a height were the most probable hazards causing injuries, while noise was reported as a hazard unlikely to cause injuries. ${ }^{11}$

Additionally, falling from a height was considered the most harmful hazard, causing injuries that require medical intervention. Those findings are consistent with Elsafty et al. who reported that falls represent about $33 \%$ of all construction fatalities. ${ }^{15}$ 
When estimating the risk perception of the studied hazards among workers, the present study showed that the majority of the workers had low risk perception for all the hazards with the exception of the noise that had between "no" or "acceptable" risk perception by nearly half of the workers. This disagrees with the study of Antonucci et al. which revealed that the workers considered all the hazards as medium risk hazards. ${ }^{11}$

Such discrepancy could be explained by the fact that most of Egyptian workers may be culturally optimistic, referring to people's perception that negative events are less likely to happen to the individuals than to one's peers, that is, "it won't happen to me"; about two-thirds $(61.5 \%)$ of the workers are not aware of the consequences of these hazards, which resulted from the lack of training. ${ }^{16}$

The current study found that four out of nine risk factors were associated with proper risk perception of different construction hazards: older age of the workers as the older workers perceived the hazard as "no/ low risk category"; health and safety training where the workers who received training had higher perception level; working hours where the prolonged working hours affected the perception level negatively; the use of PPE as the workers who were not using PPE were found to have lower level of perception toward the studied hazards. These factors and others were reported as well by other studies conducted in various countries. Elsafty et al. study reported the positive impact of implementing educational programs on workers' perception of the hazards. ${ }^{15}$

Similarly, a study performed in 2008 by Arezes and Miguel among workers in Scotland found that there were statistically significant differences between the workers' risk perception and their age and the use of PPE $(\mathrm{P}<0.001)^{17}$ In 2014, Perlman et al. also found that workers with more work experience and more formal safety training perceived the level of risk higher compared to those with little work experience and little formal safety training. ${ }^{18}$

However, this disagrees with study conducted by Antonucci et al. . and revealed that training courses had a limited influence on the workers' perception of risks. ${ }^{11}$ Identifying factors related to risk perception of various construction hazards would raise an alarm to mitigate these factors as most of them can be modified through proper health education messages and practical training to the participating workers and employers to improve their risk perception and prevent further occurrence of injuries in the future. 
Conclusions: The study concluded that risk perception among studied workers in average is low. Older age of the workers, prolonged working hours, lack of training, and not wearing PPE are significant risk factors shaping the workers' perception.

Acknowledgments: The authors would like to acknowledge the administration of the construction project for approval for conducting the research and thank the workers who agreed to be interviewed allowing us to get valuable information.

Fund: This research did not receive any specific grant from funding agencies in the public, commercial, or not-for-profit sectors.

Conflicts of Interest: The authors report no conflicts of interest.

\section{References:}

1. Abbas R, Zalat M: Non-Fatal Occupational Injuries and Safety Climate : A Cross-Sectional Study of Construction Building Workers. Journal of Safety Science and Technology. 2013, 3(12), 6979.

2. El-Sayegh S. Risk assessment and allocation in the UAE construction industry. International Journal of Project Management. 2008, 26(4), 431- 438.

3. Occupational Safety and Health Administration (OSHA) (2017): OSHA
Data and Statistics. Available at: https://www.osha.gov/oshstats/. Accessed on 15-3-2018.

4. Pinto A, Nunes I, Ribeiro R. Occupational risk assessment in construction industry, Overview and reflection. Safety Science. 2011,49(49), 616-624.

5. National Safety Council: Risk awareness and perception of health and safety in the workplace.2017. Available at: https://www.nsc.org/work-safety/toolsresources/campbell-institute. Accessed on 15-3-2018.

6. Carriço A, Anilson R, Gomes A. Quantitative analysis of the construction industry workers, perception of risk in municipalities surrounding Salvador. Procedia Manufacturing. 2015, 3, 18461853.

7. Forteza F, Sesé A, Carretero-Gómez J. CONSRAT. Construction sites risk assessment tool. Safety Science. 2016, 89, 338-354.

8. Chan A, Yeung J, Yu C et al. Empirical study of risk assessment and allocation of public, private partnership projects in China. J. Manage. Eng. 2011, 27, 136148.

9. Flammini F, Gaglione A, Mazzocca N et al. Optimisation of security system design 
by quantitative risk assessment and genetic algorithms. Int. J. Risk Assess. Manage. 2011, 15, 205-221.

10. Fleming M, Lardner R: Strategies to promote safe behaviour as part of a health and safety management system, HSE Books. 2002.

11. Antonucci A, Giampaolo L, Zhang Q et al. Safety in construction yards: perception of occupational risk by italian building workers.European journal of inflammation. 2010, 8 (2), 107-115.

12. Loewenstein G, Weber E, Hsee $\mathrm{C}$ et al. Risk as Feelings. Safety Science. 2001, 127(2), 267-286.

13. Xia N, Wang X, Griffin $M$ et al. Do we see how they perceive risk? An integrated analysis of risk perception and its effect on workplace safety behavior. Accident Analysis and Prevention. 2017, 106, 234242.

14. Dong X: Long work hours, work scheduling and work-related injuries among construction workers in the United States. Scandinavian Journal of Work, Environment and Health, 2005, 31(5), 329-335.

15. Elsafty A, Elsafty A, Malek M. Construction Safety and Occupational Health Education in Egypt, the EU, and US Firms. Open Journal of Civil Engineering. 2012, 2(9), 174-182.

16. Caponecchia C, Sheils I. Perceptions of personal vulnerability to workplace hazards in the Australian construction industry. Journal of Safety Research. 2011, 42(4), 253-258.

17. Arezes P, Miguel A. Hearing protection use in industry: The role of risk perception: Safety Science. 2005, 43, 253 267.

18. Perlman, A, Sacks, R, Barak et al. Hazard recognition and risk perception in construction. Safety Science. 2014, 64, $22-31$ 
Table (1): Characteristics of the studied workers $(n=104)$.

\begin{tabular}{|c|c|c|}
\hline \multicolumn{2}{|l|}{ Targeted character } & No. $(\%)$ \\
\hline \multirow{4}{*}{ Age } & - $15-$ & $63(60.6)$ \\
\hline & - $30-$ & $22(21.2)$ \\
\hline & - 45 & $15(14.4)$ \\
\hline & $\cdot \geq 60$ & $4(3.8)$ \\
\hline \multirow{6}{*}{ Education } & - Illiterate & $13(12.5)$ \\
\hline & - Read and write & $12(11.5)$ \\
\hline & - Primary & $3(2.9)$ \\
\hline & - Preparatory & $15(14.4)$ \\
\hline & - Secondary/technical & $47(45.2)$ \\
\hline & - university education & $14(13.5)$ \\
\hline \multirow{3}{*}{ Marital status } & - Single & $37(35.6)$ \\
\hline & - Married & $66(63.5)$ \\
\hline & - Divorced & $1(0.9)$ \\
\hline \multirow{3}{*}{ Smoking habits } & - Current smoker & $61(58.7)$ \\
\hline & - Former smoker & $7(6.7)$ \\
\hline & - Non smoker & $36(34.6)$ \\
\hline \multirow{3}{*}{$\begin{array}{l}\text { Smoking while working } \\
\text { (no. of smokers }=61 \text { ) }\end{array}$} & - Usually & $38(62.3)$ \\
\hline & - Sometimes & $11(18.0)$ \\
\hline & - Never & $12(19.7)$ \\
\hline
\end{tabular}

Table (2): Work-related characteristics of the studied workers ( $n=104)$.

\begin{tabular}{|c|c|c|c|}
\hline \multicolumn{2}{|l|}{ Work-related characteristics } & No. (\%) & \\
\hline \multirow[b]{2}{*}{ Type of contract } & Full time & $23(22.1)$ & \\
\hline & Part time & $81(77.9)$ & \\
\hline \multirow{8}{*}{ Job title } & Painter & $30(28.8)$ & \\
\hline & Carpenter & $21(20.2)$ & \\
\hline & Laborer & $19(18.3)$ & \\
\hline & Supervisor & $14(13.5)$ & \\
\hline & Builder & $10(9.6)$ & \\
\hline & Iron worker & $5(4.8)$ & \\
\hline & Sculptor & $5(4.8)$ & \\
\hline & $\begin{array}{l}\text { Range (min- } \\
\text { max) }\end{array}$ & Median & $\begin{array}{c}\text { Mean } \\
\pm \text { SD }\end{array}$ \\
\hline Working hours per week & $62(10-72)$ & 48 & $50.5 \pm 8.4$ \\
\hline $\begin{array}{l}\text { Duration of working in } \\
\text { construction in years }\end{array}$ & $49.5(0.5-50)$ & 10 & $14.2 \pm 12.2$ \\
\hline Duration of current job in years & $39.9(0.1-40)$ & 2 & $5.8 \pm 8$ \\
\hline
\end{tabular}


Table (3): Experience of work-related injuries among the studied workers $(n=104)$

\begin{tabular}{|c|c|c|}
\hline \multicolumn{2}{|c|}{ Work-related injuries characteristics } & No. $(\%)$ \\
\hline $\begin{array}{l}\text { Experience of injuries during } \\
\text { last year }\end{array}$ & $\begin{array}{l}\text { - } \mathrm{Yes} \\
\text { - } \mathrm{No}\end{array}$ & $\begin{array}{l}62(59.6) \\
42(39.4)\end{array}$ \\
\hline \multirow{5}{*}{ Type of injuries* } & - Contusions & $50(48.1)$ \\
\hline & - Abrasion & $47(45.2)$ \\
\hline & - Fractures & $39(37.5)$ \\
\hline & - Eye and ear injuries & $36(34.6)$ \\
\hline & - Disc prolapsed & $4(3.8)$ \\
\hline Medical intervention & - Yes & $23(37.1)$ \\
\hline Hospital admission & - Yes & $4(6.5)$ \\
\hline \multirow{2}{*}{ Work days missed } & - Mean \pm SD & $17.9 \pm 65.7$ \\
\hline & - Min - Max & $0-365$ \\
\hline
\end{tabular}

*More than one injury could be confronted

Table (4): PPE used by the studied workers ( $n=104)$.

\begin{tabular}{|l|l|l|}
\hline \multicolumn{2}{|l|}{} & No. (\%) \\
\hline \multirow{3}{*}{ Use of protective equipment } & $\begin{array}{l}\text { - Yes } \\
\text { - No }\end{array}$ & $\begin{array}{l}71(68.3) \\
33(31.7)\end{array}$ \\
\hline \multirow{4}{*}{ Type of PPE used* } & - Safety shoes & $60(57.7)$ \\
\cline { 2 - 3 } & - Gloves & $39(37.5)$ \\
\cline { 2 - 3 } & - Vest & $31(29.8)$ \\
\cline { 2 - 3 } & - Helmet & $30(28.8)$ \\
\cline { 2 - 3 } & - Back strap & $8(7.7)$ \\
\cline { 2 - 3 } & - Google & $3(2.9)$ \\
\cline { 2 - 3 } & - Mask & $3(2.9)$ \\
\hline
\end{tabular}

*More than one method could be used 
Table (5): Studied workers' risk perception towards the studied hazards $(n=104)$.

\begin{tabular}{|l|c|c|c|c|}
\hline Hazards & No. $(\%)$ & No. $(\%)$ & No. $(\%)$ & No. (\%) \\
\hline - Fall & $4(3.9)$ & $46(45.1)$ & $39(38.2)$ & $13(12.7)$ \\
\hline - Struck by object & $27(26.0)$ & $60(57.7)$ & $16(15.4)$ & $1(1.0)$ \\
\hline - Contact with chemicals & $31(30.1)$ & $72(69.9)$ & $0(0.0)$ & $0(0.0)$ \\
\hline - Collapse & $34(32.7)$ & $40(38.5)$ & $28(26.9)$ & $2(1.9)$ \\
\hline - Manual lifting & $5(4.9)$ & $57(55.3)$ & $29(28.2)$ & $12(11.7)$ \\
\hline - Sharp objects & $23(22.1)$ & $53(51.0)$ & $23(22.1)$ & $5(4.8)$ \\
\hline - Noise & $14(13.6)$ & $57(55.3)$ & $32(31.1)$ & $0(0.0)$ \\
\hline - Heat & $51(49.0)$ & $40(38.5)$ & $13(12.5)$ & $0(0.0)$ \\
\hline
\end{tabular}




\section{الملخص العربى}

\section{إدرالك المخاطر والحوادث المهنية بين مجموعة من عمال البناء المصريين بالقاهرة_مصر}

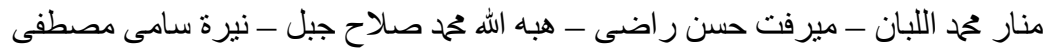

الخلفية: قطاع البناء هو واحد من الأعمال الخطرة التي تحدث فيها إصابات مهنية ممينة و غير مميتة بشكل متكرر . بمكن أن تساعد المعلومات عن وعي العمال بالمخاطر الصحية وتصور المخاطر وممارسات العمل الآمنة في تطبيق استراتيجيات الوقاية. لسوء الحظ ، فإن التناول البحثى لمواقع البناء محدودً ؛ حيث تمثل الدراسات فيه 2.28 ٪ من جميع البحوث المتاحة. الأهداف: تقدير تصور عمال البناء للأخطار المهنية ، و تحديد أنواع الحوادث المهنية الثائعة بين عمال بناء في شركة مصرية وتحديد العوامل الثخصية للعمال ومميز ات خصائص العمل المتعلقة بإدر اكهم للمخاطر. طرق البحث: تم إجر اء در اسة مقطعية بين عمال البناء في أحد المشروعات بالقاهرة. خلال الفترة من يناير إلى أغسطس 2018 ؛ وأجريت مقابلات مع عينة من 104 عمال باستخدام استبيان منظم يستفسر عن الخصائص الاجتماعية ـ الديمغر افية ، و المتغير ات المرتبطة بالعمل جنبا إلى جنب مع تقييم إدر الك مخاطر العمال. النتائج: كان لاى غالبية العمال إدر الك منخفض لمخاطر السقوط ، و التعامل مع المواد الكيميائية ، و الاصطدام بالأشياء ، و الأشياء الحادة ، والرفع اليدوي ، والحركات المتكررة ، و الإجهاد الحراري ، في حين تم اعتبار الضوضاء بأنها "فئة اللا مخاطر أو المخاطر المقبولة". أظهرت الدر اسة أن العمر وتدريب الصحة و السلامة وساعات العمل و استخدام معدات الحماية الشخصية كعو امل ذات صلة إلى حد كبير بإدر الك المخاطر. الخلاصة: إدر الك المخاطر بين العمال المدروسين في المتوسط منخفض. يعد السن الأكبر وساعات العمل المطولة ونقص التدريب و عدم ارتداء معدات الحماية الثخصية عو امل خطر كبيرة تشكل إدرالك العمال. التوصية: قد يقلل التدريب على السلامة وتغيير بيئة العمل من خطر وقوع إصابات. 